INTERNATIONAL JOURNAL OF RESEARCHES IN BIOSCIENCES, AGRICULTURE AND TECHNOLOGY (C) VISHWASHANTI MULTIPURPOSE SOCIETY (Global Peace Multipurpose Society) R. No. MH-659/13(N) wWw.ijrbat.in

\title{
AN ETHNOBOTANICAL STUDY OF PINGULI VILLAGE IN KUDAL TEHSIL OF SINDHUDURG DISTRCT OF MAHARASHTRA.
}

\author{
Borate Pallavi P. and Meena S. Rao
}

Abstract:

Department of Botany, R. K. T. College, Ulhasnagar, Thane (M. S., INDIA).

\begin{abstract}
The present study represents a part of a wider ethnobotanical survey conducted in different localities of Pinguli tehsil (Dist. Sindhudurg, M. S., INDIA) during May-July 2017. The survey was done by face-to-face interview of 84 people residing in the tehsil. The participants were asked: 1) to list medicinal plants used by them (excluding Justica adhatoda L., Calatropis gigantia L., Cassia tora L., Syzigium cumini (Linn.), Garcinia indica Choisy and 2) to present a detailed information about local names of plants listed, ethnobotanical use and the mode of application. Totally 31 plant species were listed by respondents. The plants were collected and identified with the help of pertinent literature. The most frequently reported plants are - Emblica officinalis Gaertn, Santalum album (L.), Terminalia arjuna (Roxb.) W. \& A., Phyllanthus niruri non L., Carrissa congesta carandus L., Hyptis suaveolens Poit .These plants are used mainly for disease prevention and treatment. The information reported by the participants in this study is an evidence for the existence of local knowledge of folk medicine in Pinguli area of Kudal taluka in Sindhudurg Distrct. At the same time, the interest and use of non-native plants display the impact of globalization and socio-cultural development on herbal utilization.

Keywords: Ethnobotanical survey, medicinal plants, disease prevention and treatment.
\end{abstract}

\section{Introduction}

Ethnobotany is broadly defined as the study of the relationship between plants and people (McClatchey, 2009). Ethnobotany is considered as a branch of ethnobiology. Ethnobotany studies the complex relationships between (uses of) plants and cultures. The focus of ethnobotany is on how plants have been or are used, managed and perceived in human societies and includes plants used for food, medicine, divination, cosmetics, dyeing, textiles, for building, tools, currency, clothing, rituals and social life (Rahman, 2009). Ethnobotany, in its totality, is virtually and old field with new dimension of research. It will appear to be a bridge between botany and medicinal plants, but in fact it is much more. It starts as step before ever botany in the sense supplies the 'idea' and the basic material for botanical research and study. It then takes us to the usefulness of medicinal plants. It goes a step ahead to help us in the application of the knowledge about the medicinal plants among the primitive people by rapport through the medicine men (Jain, 1996).

Pinguli is very rich in ethnocultural heritage and traditional use of plant materials that may be of special interest in ethnobotanical information. During ethnobotanical field studies in the area, we came across a large number of "-tribal and local people" who are using wild and semi-wild plants for medicine and other purposes. They are well experienced in traditional medicine and are actually prescribing these plants materials to cure different diseases. The present paper is restricted to the medicinal uses of 36 such plants. The data were collected either from traditional healers or ordinary people who accompanied us in the field. This is for the first time ethnobotanical research is carried out in the study area. The aims of the study are:

A) To make an investigation about the present ethnobotanical status of the study area

B) Documentation of medicinal plants available in the study area and

C) To know the extent of use of medicinal plants by the tribal and local people (Rahman, 2009).

\section{Materials and Methods}

The present work is mainly based on information gathered from the interview with the "Traditional healers" on the plants having economic importance to them. Relevant plants were collected from the study area, identified and preserved by making herbaria. The present investigation is divided into two parts: Part I. Interviews, collection, identification and preservation of plants: and

Part II. Study of ethnobotanical aspects.

\section{Part I. Interviews, collection, identification} and preservation of plants:

First step was interviewing the "traditional healers" about the plants they used in their daily life. These include the plants that have some economic importance as fruits, vegetables, furniture, drug, etc. Collections were made throughout the study period and particular care was taken not to miss the flowering stages or the fruits. In all cases multiple sets of collections were made. During collection attempts were made to know the 
local names of the plants. All field data that cannot be observed from the herbarium specimen e.g. date, collection number, habitat, uses and distribution were recorded. Herbarium sheets were prepared in multiple sets and flowers were preserved in $70 \%$ alcohol for future study. The collected plant specimens were identified and information collected from "traditional healers" about their medicinal uses is verified by referring standard literature (Agharkar (1991); Ahmed (2008); Alam (1992); Anisuzzaman (2007); Bhattachariya (1989); Biswas (1973); Dey (1996); Ghani (1988, 1998); Hassan (1988, 1993), Hooker (1877), Huq (1986, 1986), Koche et al. (2008), Khan (1975, 1998); Khan et. al. (2002); Kirtikar (1987); Prain (1903); Rahman (2008, 2009, 2010, 2011, 2012), Roy et. al. (2008) and Sing (1998-2001)).

\section{Part II. Study of ethnobotanical aspects:}

In present investigation "Traditional healers" in the study area were interviewed for collecting information on different aspects such as, a) Owner of the house, b) Family members and age groups c) Source of income, d) List of plants used by them, e) Purpose of use, f) How much amount they use, g) Method of use, h) From where they collect the plants i) What is time of collection and j) Abundance of the plants..

\section{Result:}

Ethnobotanical data is gathered on the traditional uses of plant species, especially for abscess, asthma, abortion, burning sensation, blood pressure, cough, chickenpox, constipation, dysentery, diarrhoea, diabetes, eczema, fever, fracture, headache, heart disease, itches, jaundice, menstrual disease, paralysis, skin disease, snakebite, sex problem, tooth disease, vomiting, wound, worm and others by using survey, interview, collection and identification methods. The data obtained is presented in table no. 1 .

\section{Discussion:}

Since its conception in 1895 'ethnobotany' has proved a rather difficult term to define (Harshberger, 1896). Harshberger himself regarded it in a simpler way as 'the use of plants by aboriginal peoples', Yet, during the century considerable attention has focused not only on how plants are used, but also on how they are perceived and managed, and on the reciprocal relationships between human societies and the plants on which they depend. As a result, ethnobotany has been repeatedly redefined and even now no definitive agreement in its interpretation has been reached (Yen, 1993). However, for the purposes of this text, ethnobotany is considered to encompass all studies which elucidate the mutual relationships between plants and the traditional healers.

The present study deals with the medicinal plants of Pinguli, (Taluka Kudal, District Sindhudurg, Maharashtra State) used by traditional healers. Much of the expansion and diversification of ethnobotany has occurred in the last 25 years, during which it has developed into a truly multidisciplinary field of natural science, combining the talents of anthropologists and archaeologists with those of molecular biologists and ecologists. More recently, however, there has been an increasing awareness of the considerable practical and social value of traditional knowledge, and many workers are becoming involved in applied ethnobotany- the practical application of ethnobotanical data in areas such as biodiversity and prospecting \& conservation biology. For example, ethnobotanical investigations by the San Fransisco-based company, Shaman Pharmaceuticals Inc. have already led to the development of two antiviral products which are now in clinical trials (King and Tempesta, 1994), while indigenous management practices have been shown to have a profound influence on factors such as plant genetic diversity and habitat conservation (Soleri and Cleveland, 1993; Rajasekaran and Warren, 1994). Ethnobotanical data have been gathered on the traditional uses of plant species, especially for abscess, for asthma, for abortion, burning sensation, blood pressure, cough, chickenpox, constipation, dysentery, diarrhoea, diabetes, eczema, fever, fracture, headache, heart disease, itches, jaundice menstrual disease, paralysis, skin disease, snake-bite, sex problem, tooth disease, vomiting, wound, worm and others (Anisuzzaman et. al., 2007; Rahman et. al., 2008).

It was observed that the availability of these plants was decreasing at an alarming rate. This observation also reveals that habitat destruction, over exploitation and unplanned agriculture by human are the reasons for depletion of medicinal plants population and diversity too. Therefore, the medicinal plants used as traditional healthcare system need urgent conservation measures (Rahman et. al., 2011). Very recently, a new field of ethnopharmacology has been evolved to harvest very specific bioactive molecules from the plants parts being used by traditional 
healers. This may help in reducing the random use of plant parts to treat the ailments traditionally.

\section{Conclusion:}

The study revealed that the traditional healers are using the plant resources in crude format. This is likely to create the problem of loss of valued plants. Hence, more study is needed on their way of collection and application of plant materials. Attempts are needed to study these plant materials at biochemical level and purified active components must be tested against respective disease causing pathogens, so that the crude extracts can be converted to fine drugs.

\section{Acknowledgement:}

Authors are thankful to officers from forest department for providing the information of natural healers in the study area. We are also thankful to the Principal of R.K.T. College, Ulhasnagar for promoting to undertake such study and providing laboratory facilities.

\section{Bibliography}

Agharkar, S. P. (1991): Medicinal Plants of Bombay Presidency. Scientific Publishers, Jodhpur, India.

Ahmed, Z. U. (2008): Encyclopedia of Flora and Fauna of Bangladesh. Asiatic Society of Bangladesh, Dhaka-1000, Bangladesh. 6:263359.

Alam, M. K. (1992): Medical ethno-botany of the Marma tribe of Bangladesh. Econ. Bot. 46(3):330335

Anisuzzaman, M., Rahman, A.H.M.M., HarunOr-Rashid, M, Naderuzzaman, A. T. M. and Islam, A. K. M. R. (2007): An Ethnobotanical Study of Madhupur, Tangail. J. App. Sci. Res. 3(7):519-530

Bhattachariya, S. (1989): Chirangiby Bonoushadi, Ananda Publisher Ltd., Calcutta. Vols. 1-10.

Biswas, K. (1973): Bharatio Banoushadi, Vols. IVI, Calcutta University Press, Calcutta

Dey, T. K. (1996): Useful Plants of Bangladesh. The Ad. Communication, 385, Sirajuddowlah Road, Anderkilla, Chittagong, Bangladesh Ghani A (1998). Medicinal Plants of Bangladesh. Asiatic Society of Bangladesh, Dhaka.

Harshberger, J. W. (1896): The purposes of ethnobotany. Botanical Gazette 21:146-154.

Hassan, M. A. (1988): Amader Banoushadi Shampad, Hassan Book House, Dhaka.

Hassan, M. A. and Huq, A. M. (1993): Gas Gasra Deeya Chikithsha, Hassan Book House, Dhaka, Bangladesh. Hooker J. D. (1877). Flora of British India, Reeve and Co. Ltd., London. Vols. 1-7.
Huq, A. M. (1986): Name Changes in Bangladesh Angiosperms. Bangladesh National Herbarium, BARC, Dhaka, Bangladesh.

Huq, A. M. (1986): Plant Names of Bangladesh. Bangladesh National Herbarium, BARC, Dhaka, Bangladesh.

Jain, S. K. (1996): Glimpses of Indian Ethnobotany, Oxford \& IBH Publishing Co. New Delhi, Bombay, Calcutta

Khan, M. S. (1998): Prospects of Ethnobotany and Ethnobotanical Research in Bangladesh. In: Applied Ethnobotany, Banik R. L., Alam M. K. , Pei S. J. and A. Rastogi (eds.), BFRI, Chittagong, Bangladesh. pp. 24-27.

Khan, M. S. and Huq, A. M. (1975): Medicinal Plants of Bangladesh, BARC, Dhaka, Bangladesh. Khan, M. S., Hassan M. A. and Uddin, M. Z. (2002): Ethnobotanical survey in Rema Kalenga Wildlife Sanctuary (Habiganj) in Bangladesh. Bangladesh J. Plant Taxon. 9(1):51-60

Kirtikar, K. R. and Basu, B. D. (1987): Indian Medicinal Plants. Lalit Mohan Basu, Allahabad, Jayyed Press, New Delhi, India. 1-4:1313-1449.

McClatchey, w. C., Mahady, G. B. Bennett, B. C., Shiels. L. and V. Savo, (2009): Ethnobotany as a pharmacological research tool and recent developments in CNS-active natural products from ethnobotanical sources. Pharmacology \& Therapeutics, 123: 239-254.

Prain, D. (1903): Bengal Plants, Botanical Survey of India, Calcutta. Vols. 1- 2. Rahman A. H. M. M., Anisuzzaman M, Haider S. A., Ahmed F.A.K.M. Islam A. K. M. R. and A. T. M. N. Zaman (2008). Study of Medicinal Plants in the Graveyards of Rajshahi City. Res. J. Agric. Biol. Sci. 4(1):70-74.

Rahman, A. H. M. M. (2009): Taxonomic Studies on the Family Asteraceae (Compositae) of the Rajshahi division. Ph.D. thesis, Department of Botany, University of Rajshahi, Bangladesh.

Rahman, A. H. M. M., Islam A. K. M. R. and Rahman, M. M. (2011): The Family Asteraceae of Rajshahi Division, Bangladesh, VDM Verlag Dr. Muller Publishing House Ltd., Germany.

Rahman, A. H. M. M., Jahan-E-Gulsan M. S., Alam M. S., Ahmad S., Zaman A. T. M. N. and Islam, A. K. M. R. (2012): An Ethnobotanical Portrait of a Village: Koikuri, Dinajpur with Reference to Medicinal Plants. Int. J. Bio. Sci. 2(7):1-10

Rahman, A. H. M. M., Kabir E. Z. M. F., Sima S. N., Sultana R. S., Nasiruddin M.and Zaman, A. T. M. N. (2010): Study of an Ethnobotany at the Village Dohanagar, Naogaon. J. App. Sci. Res. 6(9):1466-1473.

Rajasekaran, B. and Warren, D. M. (1994): Indigenous Knowledge for socioeconomic development and biodiversity conservation: the Kolli hills. Indigenous Knowl. Dev. Monit. 2(2):1317 
Roy, S., Uddin, M. Z., Hassan, M. A. and Rahman, M. M. (2008): Medico-botanical report on the Chakma community of Bangladesh. Bangladesh Jour. Plant Taxon. 15(1):67-72

Sing, A. P. (1998-2001): Ethnobotanical Studies of Chandigarh Region. Mohali, India.
Soleri, D. and Cleveland, D. A. (1993): Hopi crop diversity and change. J. Ethnobiol. 13:203232

Yen, D. E. (1993): The origin of subsistence agriculture in Oceania and the potentials for future tropical food crops. Econ. Bot. 47:3-14.

Table No.1: Table No. 1. Ethnobotanical survey in Pinguli area.

\begin{tabular}{|c|c|c|c|c|}
\hline Sr.No. & Botanical Name & $\begin{array}{l}\text { Local } \\
\text { Name }\end{array}$ & Part used & Ethnobotanical Use \\
\hline 1 & Emblica officinalis Gaertn & Awala & Fruits & vomiting \\
\hline 2 & Santalum album (L.) & Chandan & Bark \& leaves & Cooling effect, oil used in cosmetics \\
\hline 3 & $\begin{array}{l}\text { Terminalia arjuna (Roxb.) } \\
W \& A\end{array}$ & Arjun & Bark \& roots & $\begin{array}{l}\text { To cure headache, during injury, blood } \\
\text { pressure }\end{array}$ \\
\hline 4 & Phyllanthus niruri non $L$. & Bhuiawala & Leaves & Diuretic, laxative and cardio protective \\
\hline 5 & $\begin{array}{l}\text { Carrissa congesta } \\
\text { carandus } L .\end{array}$ & Karvand & Fruits & Antiscorbutic, used against snake bite \\
\hline 6 & Hyptis suaveolens Poit & Rantulas & Leaves & Fever, decoction used in cold and cough \\
\hline 7 & $\begin{array}{l}\text { Sapindus emarginatus } \\
\text { (Vahl) }\end{array}$ & Ritha & $\begin{array}{l}\text { Fruits \& } \\
\text { leaves }\end{array}$ & Tonic expectorant, good shampoo \\
\hline 8 & Bombax ceiba $(L)$ & Katesawar & Bark & Diuretic, tonic \\
\hline 9 & Rauwolfia serpentine (L). & Sarpgandha & $\begin{array}{l}\text { Leaves \& } \\
\text { roots }\end{array}$ & Snake bite, stomach pain \\
\hline 10 & Plumeria rubra (Lim.) & Chapha & Bark & Bark juice used on wound \\
\hline 11 & $\begin{array}{l}\text { Holarrhena } \\
\text { antidysenterica }(L),\end{array}$ & Kuda & $\begin{array}{l}\text { Fruits \& } \\
\text { roots }\end{array}$ & Used in urine stones, worms \\
\hline 12 & Euphobia tirucalli $(L)$ & Sher & Bark \& roots & Administered in colic and gastralgia \\
\hline 13 & $\begin{array}{l}\text { Aegel mermelos (Corr -ex- } \\
\text { roxb). }\end{array}$ & Bel & $\begin{array}{l}\text { Leaves, bark } \\
\& \text { roots }\end{array}$ & Reduces cold and cough \\
\hline 14 & Gmelina arborea (Roxb.) & Shivan & Fruits & Applied on tumors, antiviral \\
\hline 15 & Tectona Grandis (Linn.f.) & Sag & Wood & Diuretic, expectorant, sedative \\
\hline 16 & Acacia catechu (Arn). & Khair & Bark & Antileprotic activity, refrigerant \\
\hline 17 & Acacia indica (Brenan). & Babhul & Gum & $\begin{array}{l}\text { Stops bleeding, urinary and vaginal } \\
\text { discharges }\end{array}$ \\
\hline 18 & Annona reticulata $(L)$. & Ramphal & Bark, Fruits & Astringent , stops diarrhea \\
\hline 19 & Annona squmosa (L). & Sitaphal & Seeds & kills head louse \\
\hline 20 & Moringa oleifera (Lam). & Shevaga & Leaves & Reduces blood sugar level \\
\hline 21 & Ficus benghalensis $(L)$. & Wad & Leaves & $\begin{array}{l}\text { Applied on affected places to treat } \\
\text { wounds. }\end{array}$ \\
\hline 22 & Ficus hispida(L.F.) & Bhui umber & Latex, fruits & Used as lotion \\
\hline 23 & Ficus racemosa $(L)$. & Umber & Roots & Root juice is good to heal wounds. \\
\hline 24 & Ficus religiosa $(L)$ & Pimpal & Leaves & $\begin{array}{l}\text { Dried leaf powder used to get relief from } \\
\text { body pain }\end{array}$ \\
\hline 25 & $\begin{array}{l}\text { Azadirecta indica } \\
\text { (A.Juss) }\end{array}$ & Neem & Leaves & $\begin{array}{l}\text { Leaves used for bath to avoid skin } \\
\text { infections. }\end{array}$ \\
\hline 26 & $\begin{array}{l}\text { Bauhinia recemosa } \\
\text { (Lam). }\end{array}$ & Apta & $\begin{array}{l}\text { Leaves \& } \\
\text { bark }\end{array}$ & $\begin{array}{l}\text { Antidysentric, inflammatory, used in } \\
\text { diarrhea }\end{array}$ \\
\hline 27 & Tamarandus indica $(L)$. & Chinch & $\begin{array}{l}\text { Fruits } \& \\
\text { leaves }\end{array}$ & $\begin{array}{l}\text { Dried fruits are taken orally to treat eye } \\
\text { infection. Used to treat ulcer. }\end{array}$ \\
\hline 28 & Delonix regia (B.Hook.) & Gulmohar & $\begin{array}{l}\text { Seeds \& } \\
\text { leaves }\end{array}$ & $\begin{array}{l}\text { Used against constipation, } \\
\text { inflammation. }\end{array}$ \\
\hline 29 & $\begin{array}{l}\text { Bambusa arundinacea } \\
\text { (Retz.)Wild }\end{array}$ & Bamboo & Roots & $\begin{array}{l}\text { Expectorant, } \\
\text { Veterinary medicine }\end{array}$ \\
\hline 30 & Nyctanthes arbortrits $(L)$. & Parijatak & Bark & $\begin{array}{l}\text { Stops bleeding of gums, used on cold } \\
\text { and cough }\end{array}$ \\
\hline 31 & Pongamia pinnata $(L)$. & Karanj & Fruits & $\begin{array}{l}\text { Oil extracted from seeds is applied on } \\
\text { affected places to treat wounds. }\end{array}$ \\
\hline
\end{tabular}

